\title{
DIGITALCOMMONS
}

@WAYNESTATE-

Wayne State University

Library Scholarly Publications

Wayne State University Libraries

$1-21-2016$

\section{Use of Mobile Devices to Access Resources Among Health Professions Students: A Systematic Review}

Misa Mi

William Beaumont School of Medicine Library, Oakland University, Rochester, MI

Wendy Wu

Shiffman Medical Library, Wayne State University, Detroit, MI, wendywu@med.wayne.edu

Maylene Qiu

Biomedical Library, University of Pennsylvania, Philadelphia, PA

Yingting Zhang

RWJ Library of the Health Sciences, Rutgers, The State University of New Jersey, New Brunswick, NJ

Lin Wu

Medical Sciences Library, Texas A\&M University, Kingsville, TX

See next page for additional authors

\section{Recommended Citation}

Mi, M., Wu, W., Qiu, M., Zhang, Y, Wu, L. \& Li, J. (2016). Use of mobile devices to access resources among health professions students: a systematic review. Medical Reference Services Quarterly, 35(1), 64-82. DOI:10.1080/02763869.2016.1117290

Available at: http://digitalcommons.wayne.edu/libsp/108

This Article is brought to you for free and open access by the Wayne State University Libraries at DigitalCommons@WayneState. It has been accepted for inclusion in Library Scholarly Publications by an authorized administrator of DigitalCommons@WayneState. 
Authors

Misa Mi, Wendy Wu, Maylene Qiu, Yingting Zhang, Lin Wu, and Jie Li 


\title{
Use of Mobile Devices to Access Resources among Health Professions Students:
}

\section{A Systematic Review}

\begin{abstract}
Objectives: This systematic review examines types of mobile devices implemented in health professions education, kinds of resources and tools accessed by health professions students via mobile devices, and reasons for using mobile devices to access the resources and tools.

Methods: The review included studies published in English between January 2010 and April 2015 with empirical data retrieved from PubMed, EMBASE, CINAHL and eight other databases.. Data extracted included participants characteristics, study design, mobile devices used, mobile resources/apps accessed, outcome measures, outcomes, and advantages of and barriers to using mobile devices to access resources.

Results: The authors identified 20 articles that satisfied the inclusion criteria. There was significant variability across the studies in terms of research methods, types of mobile programs implemented, resources accessed, and outcomes. The majority of the studies show higher acceptability and usability of mobile devices for activities pertaining to resources utilization, learning, and patient care.

Conclusions: Beneficial effects of using mobile devices to access a wide range of knowledgebased resources and mobile apps were evidenced through the synthesis. The findings of the studies also reveal conspicuous challenges or barriers faced by students in using mobile devices. Implications: The findings suggest immediate implications for health sciences libraries and imply new opportunities for librarians to launch innovative initiatives to develop mobile programs to facilitate access to mobile resources and accelerate integration of mobile technologies into teaching, learning, and clinical practice.
\end{abstract}

Funding: Research was performed with no external funding. 


\section{Keywords}

Computers, Handheld; Cell Phones; Information Seeking Behavior; Access to Information;

Students, Health Occupations; Students, Medical; Students, Nursing; Students, Pharmacy;

Students, Public Health; Education, Medical Graduate 


\section{INTRODUCTION}

The stewardship of high-quality information has always been at the center of a librarian's mission [1]. Libraries are experiencing a shift from information place to information space [2]. T. Scott Plutchak contends that librarians are more necessary than ever in helping members of their communities navigate the increasingly complex information space [3]. The near ubiquity of mobile devices among clinicians [4] in the current digital age may contribute to the shift in health sciences libraries. Mobile devices are changing the landscape of health care and e-learning environments. They are being used to extend the human mind's limited capacity to recall and process vast amount of relevant data to support information management, general administration, and clinical practice [5]. Gaglani and Topol argue that medical schools should make efforts to integrate mobile technologies into their curriculum [4]. Raman points out that work is necessary to make mobile devices more easily accessible to students and to encourage and enhance the practice of working with mobile technology in nursing education [6].

Health sciences librarians are quick to spring into action in response to the widespread use of mobile technology. They have been taking various initiatives to incorporate mobile technologies and resources in health professions education by instructing on proper uses of mobile technologies and resources [7], connecting health professionals to clinically relevant mobile resources and library services [8], designing library websites to meet mobile information needs [9], and creating mobile optimized subject guides to facilitate medical students' access to mobile resources and tools $[7,10]$.

Clearly, libraries have made great strides in support of adoption of mobile devices and utilization of mobile resources and applications for different purposes and activities. Health sciences librarians need to continue to advance towards the goals of making mobile devices and 
resources more easily accessible and incorporating mobile resources in curricula and developing strategies to address existing concerns and barriers associated with mobile technologies.

In face of all the rapid development of mobile technologies and increased utilization of mobile devices in clinical practice and health professions education, it is essential for health sciences librarians to become cognizant of a variety of resources and tools accessed via mobile devices and to develop awareness of concerns and issues associated with the use of mobile devices. A systematic review was conducted to address research questions of what types of mobile devices were implemented in health professions education, what kinds of mobile resources and tools different groups of health professions students accessed and used, and what activities they were engaged in using mobile devices as a means to access resources and tools.

Systematic knowledge of the evidence pertinent to these questions would aid health sciences librarians when launching various initiatives such as allocating adequate funding to develop mobile resource collections, developing programs to educate users about mobile apps, embedding mobile devices within existing or future curriculum design and delivery, and developing creative strategies to overcome concerns with or barriers to using mobile devices. In the digital age, libraries are poised to play various roles that will enable them to emerge as institutional change agents [11].

\section{METHODS}

\section{Data Sources}

Databases searched included PubMed, EMBASE, CINAHL, ERIC, Web of Science, Scopus, PsycINFO, Cochrane Library, ProQuest Dissertations \& Theses, Academic OneFile, and Google Scholar. The reference lists of identified studies were also hand-searched. Search strategies were created and peer-reviewed by librarians. Index terms identified were specific to each database/resource and related to key concepts of mobile devices, information resources, and health professions students. Search strategies included combinations of index terms and text 
words for each database/resource. Search terms and strategies included, but not limited to: (mobile devices OR cell phones OR mobile phones OR mobile applications OR handheld computers OR mobile devices OR wireless technologies OR mobile technologies OR personal digital assistants OR personal digital devices ipad* OR iphone* OR android OR smartphone* OR tablet* OR ipod* OR microcomputer*) AND (information seeking behavior OR information resources OR information storage and retrieval OR informatics OR information management) AND terms that embraced medical students, residents, nursing students, and other allied health professions students.

\section{Study Selection}

All included studies contained empirical data in published reports investigating the impact of the implementation of mobile devices as an intervention or strategy to facilitate access to resources and mobile apps among health professions students. For the purpose of this review, health professions students are defined as undergraduate medical students, graduate medical students (residents, doctors in training), nursing students, allied health professions students, and students enrolled in other healthcare-related educational programs. Editorials, comments, general opinion pieces, letters, survey research studies, and reviews were excluded. Studies without implementing any mobile devices as an approach or strategies were also excluded. The search results were limited to English, published between January 2010 and April 2015. Two authors worked independently to screen all retrieved titles and abstracts based on the selection criteria and to select potential article candidates for the systematic review. Full text articles were obtained. Two authors read all full-text articles independently and selected articles for the final review. The third author served as a tiebreaker to resolve any disagreement.

\section{Data Extraction}

A standardized data abstraction form was developed and utilized. Fields of data extracted included setting, participants, study design, mobile devices used, resources/apps accessed, outcome measures, and outcomes from the use of mobile devices in accessing information 
resources. A qualitative systematic review was conducted due to heterogeneity in the selected studies in terms of study designs, types of mobile devices as interventions, participants recruited, and outcome measures. Quality of articles was assessed using principles discussed in works on education research. ${ }^{12-14}$

\section{RESULTS}

The initial search of all databases and resources yielded 6,086 citations. After removing duplicated citations, excluding articles not meeting the selection criteria, 57 full text articles were examined, from which 20 articles were selected in the final review.

Figure 1 Flowchart of the literature search and study screening process in a systematic review to identify eligible studies

\section{Study Characteristics}

Of 20 studies, half of them ( $n=12)$ used quantitative research designs; 5 had mixed methods designs; and 2 employed qualitative research designs (see Table 1). Of the 12 studies, 6 were single group posttest only designs (or one short case study), 5 single group pretest-posttest designs, 1 pretest-posttest control group design with random assignment, and 1 crossover design. The 5 mixed method studies combined qualitative and quantitative approaches into their research methodology to investigate the use of mobile devices. Mixed methods use methodological triangulation that involves the use of both qualitative and quantitative approaches to studying the same phenomena within the same study [15]. The 5 studies with mixed methods included quantitative methods of pretest-posttest random control group design and one-group pretestposttest design in combination with qualitative methods such as focus group, interview, observation, and narrative report. A majority of studies $(n=17)$ used questionnaires as data collection methods; 6 studies included observation, content analysis, usage log, and feedback; 5 
studies employed focus groups; 2 studies administered objective performance tests [16,17]; only one study included interview [18]. None of the selected studies provided any evidence of reliability of the questionnaires administered to participants; only 3 studies had limited information on face and content validity of questionnaires used $[16,19,20]$.

\section{Settings}

The majority of the studies $(\mathrm{n}=15)$ reported activities related to the application of mobile devices in clinical and primary care settings. Academic setting, such as medical school, library, and classroom, was documented in other 5 studies. Since the scope of the systematic review was international, studies from all countries were included. Ten studies were conducted in the USA; 4 studies were in the UK; 1 study in Australia, Germany, Sweden, Canada, Singapore and Botswana respectively (Table 1).

Table 1 Characteristics of 21 studies

\section{Study Population}

Health professions students were the target population of studies selected for the systematic review. Among the 20 studies, 7 targeted medical students; 8 focused on residents; 7 studied nursing students; 5 studies included other groups of participants from programs in physiotherapy, midwifery, sports medicine, and residency training (Table 1). The sample size varied from one study to another with a range of 9 to 578 .

\section{Types of Mobile Devices}

Half of the 20 studies reported the implementation of the iPad as an intervention or strategy to facilitate students' resources access, enhance learning, aid patient care, and meet other needs. Eleven studies reported the use of other mobile devices including iPod, iPAQ, Smartphone, PDAs, Netbook, and Kindle e-reader. The duration for the intervention of mobile devices in the selected studies ranged from 2 weeks to 2 years. 


\section{Accessing Health Information on Mobile Devices}

Mobile devices were mostly utilized as portable tools for quick and easy access to health information resources at the point of need. Of 20 selected studies, 10 reported the use of and access to evidence-based medicine (EBM) resources via mobile devices. These resources included pre-appraised EBM resources in 3 studies, practice guidelines in 6 studies, and journal articles in 6 studies. Among the EBM resources were DynaMed, Micromedex, UpToDate, Cochrane Abstracts, and Outlines in Clinical Medicine. The majority of studies $(n=16)$ reported the use of and access to a wide array of health information resources and specialty resources applications appropriately selected for knowledge acquisition and inquiry- or self-directed learning to enhance health professions students' learning outcomes and patient care experiences at clinical settings. These resources included drug guides, handbooks, manuals, dictionaries, encyclopedias, online textbooks, lab values, nursing procedures, and specialty resources (e.g., internal medicine, radiology, pathology, neurology, neurosurgery). A few others were visual resources of mobile applications such as VisualDX [18], DrawMD [18], and anatomy atlases [2124].

\section{Accessing Learning Resources on Mobile Devices}

Another function of mobile devices was distributing learning resources to support students learning activities. These resources came in the forms of question banks, self-assessment applications [18,19,25], calculators [26,27], multimedia learning resources [16,24,28], or curriculum-related materials [24,29-31]. In a study by Bruce-Low, et al, mobile learning devices for students to use (Samsung NC10 Netbook) were loaded with a video of an ECG technique incorporating multiple choice quizzes and interactive exercise [16]. Sharpe and colleagues reported the educational impact of the iPad on resident educational experiences in their entire residency program [24]. In their study, an educational and clinical tool, Radiology Resident iPad Toolbox, was created to improve resident education and to fit various learning styles of residents as adult learners [24]. The toolbox functioned as an online educational resources portal that 
encompassed a combination of electronic textbooks, case-based learning files, major radiology journals, radiology review video lecture course, and departmental lectures. Also included in the toolbox were a number of clinical tools for accessing Electronic Medical Record (EMR), hospital call schedule, and Picture Archiving and Communication Systems (PACS), as well as communication tools for remote videoconferencing, access to didactic and case-conference lectures, audience response, and other workplace performance aids.

\section{Accessing Mobile Applications for Knowledge Management and Workplace Performance}

Other uses of mobile devices included knowledge management [17,18,25,32] and access to EMR $[18,25,29]$. The use of mobile applications to improve learning and enhance workplace performance and communications were also reported in 10 studies. Examples of these applications included a multiplatform journaling app Evernote [25], the iPad "air-play-mirroring" for presentations, FaceTime, Dropbox [29], Skyscape [33], KeyNote [17], DocTool Cross Library Search Tool [23], PDFExpert for reading and editing PDF files on the iPad, and QuickOffice [18]. Various clinical tools were used to access EMR (DICOM viewers), make call schedules, and access PACS and EMR remotely via the Citrix Receiver [24]; Cisco WebEx Meeting videoconference software was installed for iPad users to make didactic and case-conference lectures anywhere with an Internet connection; the ResponseWare app was embedded into the iPad to offer the capability of audience response during resident training events [24].

\section{Patient Care and Clinical Decision Making}

Mobile devices were introduced to health professions students as an intervention in 12 studies to improve their patient care experiences and support clinical decisions by means of quick and easy access to various health information resources, mobile applications, and tools.

\section{Medical Students' Use of Mobile Devices}

Third-year medical students reported using the iPad at all stages of patient care (before, during, and after patient encounters) [18]. Alegria et al found that the majority of third-year medical students used tablet computers (iPads) for remote access to patient records, while some students 
accessed reference information at the point of care [25]. The results of the study by Nuss and colleagues suggested that obtaining real-time patient data via the electronic health record was the most frequent way of using the iPad, followed by identifying medical knowledge resources for clinical decision support [18]. The majority of students used the iPad many times daily, and the amount of time spent using the device grew over time [18].

When comparing the use of a PC, smartphone, and tablet computer in conducting a bedside literature search on "Unbound Medline", a free PubMed app, Friederichs and colleagues noticed in their study that third-year medical students in the PC group found searching more effective than the students in the smartphone or the tablet group. The PC group reported being more eager to try a literature search during their next internship compared with the other two groups, even if all three groups had sufficient technical skills for the bedside literature search and had the same level of confidence in performing a literature search at the bedside [34]. Another mobile device, Kindle reader, was investigated for its benefits to second-year and fourth-year medical students, residents, and preceptors in accessing online textbooks in clinical settings [30]. The findings of the study indicated that the e-reader had more uses for educational support than for direct patient care. In comparison with networked computers if available, the e-reader was less efficient in direct patient care settings due to its slow processor and suboptimal wireless connection [30].

\section{Residents' Use of Mobile Devices}

In a study by Berkowitz et al, radiology residents looked up relevant anatomy and used diagnostic aids to help them identify pertinent radiographic abnormalities on the iPad [21]. The results of another study showed that neurology residents used the iPad regularly while on inpatient service. They used the tablet to access and update the sign-out list of patients, show patients magnetic resonance and computed tomography imaging at the bedside [29]. When using the same mobile devices to answer clinical questions, the types of medical applications available for use by residents can affect their performance differently. Goldbach and his associates investigated the 
effect of mobile resources on first-year residents' performance in answering clinical scenario questions. PubMed4Hh (PubMed for Handheld, a mobile application) and medical applications, both accessible on the smartphone, were compared in terms of information available to correctly answer questions related to clinical scenarios. The medical applications loaded on the mobile devices included Medscape, 5-Minute Consultant, 5-Minute Pediatric Clinical Consult, Drug Facts, Clinical Evidence, and a few others. The findings of the study showed that the residents across four residency programs (internal medicine, pediatrics, emergency medicine, and family medicine) had a significantly higher percentage of correct responses when using the medical apps for questions on drugs, diagnosis/definition, and treatment/management. PubMed4Hh had an advantage over the medical apps only for the epidemiology type of questions [33]. However, the findings of another study revealed that the majority of trainee doctors, when directly supervised, consulted senior medical staff as the most popular and frequently sought information source in the workplace followed by their peers and other staff in the medical/nursing team. Online textbooks and journals on the mobile devices were used as a just-in-time information resource in daily clinical practice when other sources were not available or when students were in the transition from medical students to first-year trainees. The use of information sources in the workplace was attributable to several factors such as ease and speed of access, perceived reliability of the information source, senior staff's experience, and application of information in context [23].

\section{Nursing Students' Use of Mobile Devices}

Brown and McCrorie noticed in their study that a majority of nursing and midwifery students were able to use the evidence on the iPad to guide clinical and care decision making at the point of care. The students also used the handheld device to answer patient questions promptly about their medication [28]. In a study of nursing students' experience with the PDA in a clinical setting, Johansson et al found that nearly half of the students used the PDA at the patient bedside. The majority of students felt the PDA was very useful, especially in homecare where there was 
limited information and no computer available to use. The PDA was perceived as being easier to carry out calculations of medicines. It boosted students' confidence, saved their time, increased quality of care and patient safety; it was a useful tool to access information at the point of need [27]. Nursing students in another study felt that the iPod touch could help facilitate delivery of nursing care and enhance the confidence of the nurses [19]. Nursing students in a study by Wittmann-Price et al reported using the smartphone to access information for medication administration, and they reported that the smartphone made it easy and faster for them to provide patient care. In light of the handheld device's positive influence on students' patient care, staff nurses supported the students' use of the handheld device as a patient care tool [35]. However, Johansson and colleagues noticed that few students were convinced that the PDA filled the same need in hospitals where there were abundant resources such as stationary computers, laptops, paper based guidelines, and card index available [27]. Over half of nursing students in a study by Hudson and Buell did not use the PDA in clinical practice [36]. Similarly, a study by Morris and Maynard showed a low utilization of iPad at the clinical setting, primarily due to practical difficulties associated with accessing the Internet and small screen size on the device [20].

\section{Mobile Resources to Support Student Learning}

Apart from the use of mobile devices to access resources for patient care and clinical decision support, 16 studies reported multiple uses of mobile devices in accessing resources to enhance individual learning activities and improve education. Medical students used mobile devices to access medical knowledge resources and curriculum-related documents [18,32], prepared for tests $[16,18,25]$, and assessed and tracked their learning [25,32]. The handheld device (e.g., Netbook) loaded with multimedia learning materials and quizzes enabled students to gauge their level of understanding and engagement in learning and thus, significantly improved their test scores [16]. The use of the PDA consolidated learning and reinforced learned knowledge because students could repeatedly look up information. In addition, students accessed information via the PDA to make constructive use of empty time spaces during their downtime [22]. 
Compared with medical students' reaction to mobile devices in supporting learning, nursing students' opinions about mobile devices for learning were mixed. Nursing students and midwifery students in one study reported that the use of the iPad assisted with their learning in the clinical laboratory and accessing information during simulation activities and saved them in printing lecture notes in preparation for the class [28]. When nursing students were surveyed about the iPod touch, an overwhelming majority felt it was useful and helpful in their learning [19]. However, nursing students in one study didn't think that the PDA was useful in the classroom as a learning/reference tool [36]. They were concerned about themselves being perceived as unprofessional or less socially desirable with the use of the iPod in patient encounters; they indicated their intention of using the device less at post-implementation than at baseline [26].

By the same token, various uses of mobile devices by residents were reported in 5 studies. Radiology residents used the iPad during didactic and case-based conferences [21]; neurology residents used the iPad "air-play-mirroring" to give educational presentations during or shortly after rounds [29]. Gonzalez, Dusick, and Martin examined the use of mobile tablet devices within the context of a competency-based curriculum in a neurosurgery residency program [17]. In their study, neurosurgical residents used tablet computers as a primary tool to access a digital library and mobile resources. One year following the deployment of the tablet computer program, the results of a performance examination (CNS-SNS, a neurological surgery examination) showed a statistically significant improvement in global scoring and improvement in 16 of the 18 individual areas evaluated. The majority of the residents devoted more time to studying outside the hospital due to introduction of the tablet computers and mobile resource [33]. Sharpe and colleagues found a positive impact of the implementation of the Radiology iPad Toolbox on radiology residents' education and learning experience [24]. More than half of the residents reported that the iPad facilitated their access to educational materials and increased their learning efficiency. In addition, the average total number of hours spent in learning radiology 
increased since the introduction of the iPad preloaded with the toolbox [24]. The impact of the iPad on residents' learning was also reflected in their evaluation of the educational curriculum. There was a statistically significant increase in the global rating of a rotation of anesthesia for orthopedics by residents when they were provided curriculum materials on the iPad. The quality of the curriculum syllabus on the iPad was also rated higher than the print one [31].

\section{Benefits of and Challenges in Accessing Resources on Mobile Devices}

Among the 20 articles, 15 studies addressed the portability that enabled users to carry the mobile devices to different settings and enhanced a variety of activities including using mobile devices to read learning materials in a classroom setting [25,28], check emails during clinical downtime [28,34], make remote diagnosis when a diagnostic workstation was unavailable [37], and make notes at bedsides during patient encounters $[17,25,28]$. All selected studies reported the advantage of instant access to a variety of resources via mobile devices, particularly when being away from workstations. Users appreciated the benefit of using mobile devices for quick access to learning materials $[16,19,22,25,26,28,34,36-38]$, immediate access to medical resources [17-19,23$25,29,30,34,35,39]$, and electronic health records at the point of patient care $[25,38,18,29]$, as well as performing quick and simple searches for the evidence used to answer clinical questions at patient care settings $[16,24,40]$. Another unique advantage of mobile devices was availability of specially designed mobile applications discussed in 13 studies.

More than half of the reviewed studies $(n=12)$ addressed technical difficulties that users encountered. These issues include problematic WiFi or Internet connectivity at clinical settings $[19,23,25,29,32,35,38,40]$, slow processing of data $[19,23,31,35,36]$, short battery life $[30,31,36,40]$, and limited storage capacities of mobile devices [36]. The portability of mobile devices came with a trade-off. The small screen size constrained users' ability to navigate $[24,31,35]$ and browse pages $[18,24]$. Due to the small screen size and inconvenience in navigation, mobile devices might not be an ideal tool for use in performing comprehensive web searches $[19,35]$. Furthermore, there was a concern with text entry on mobile devices 
[24,26,34,37] using a virtual keyboard [25] and the small size screen inherent in tablet computers [34[. Another major concern was the cost associated with ownership of mobile devices $[16,26,28,30-32,40]$ and subscription to mobile applications $[16,22,37,40]$. Subscriptions to mobile applications, particularly subject content resources, imposed an additional burden to students, not to mention the financial cost incurred for renewing subscriptions. There were other concerns with the use of mobile devices such as preceptor or patient perceptions of student mobile device use in clinical settings as non-clinical activities or being unprofessional $[16,28,29,31,34,40]$ and safety/security and consequences associated with a stolen or lost mobile device $[16,22,28,29,32,36,41]$.

\section{DISCUSSION}

The heterogeneity in research methods in the 20 studies precluded a quantitative systematic review of literature on the use of mobile devices to access resources by health professions students. However, the review sheds light on how medical students, nursing students, residents, and other allied health students in various settings from 8 different countries used a variety of mobile devices to access a wide array of resources, mobile applications, and tools for various purposes and activities.

Mobile devices offered students a great opportunity to access and utilize a wide array of information and learning resources and application tools at a time and place when it was convenient. They served as a primary tool for accessing health information resources or locating the evidence to support evidence-based practice or clinical decision making in patient care settings $[25,28,29,33,34,37]$. They were also used for distributing learning resources and tools to enhance, consolidate, reinforce, or monitor medical and nursing students' learning $[16,18,19,21,22,28]$, and help them study for exams $[18,19,25]$. The review has generated evidence demonstrating improved resident educational experiences during residency training [17, 21,24]. An iPad Toolbox of textbooks, case files, journals, lecture notes and videos considerably 
increased residents' learning efficiency [24]; the introduction of mobile devices loaded with curriculum-related materials contributed to residents' improved performance in a neurological surgery examination [17] and their positive evaluation of the teaching quality of a rotation [31]. Research also reported the use of mobile devices to facilitate remote access to patient records [18,25,29], patient education [28,29], and knowledge management [17,18,25].

Beneficial effects of mobile devices were evidenced through studies demonstrating their portability, convenience, and instant access to a wide range of knowledge-based or learning resources and mobile apps favored by users. However, the findings of the studies suggested several conspicuous challenges or barriers faced by students in using mobile devices such as unstable WiFi/Internet connection, slow data processing, short battery life, and small screen size. There were other technical, interface, cost, security, and social perception concerns with the use of mobile devices and apps. Several studies reported nursing students' mixed comments on the usability of the PDA in classroom and clinical learning environments [36], perceptions of the iPod as being less socially desirable in patient encounters [26], a low level of utilization of the iPAQ in a clinical setting [39], and less likelihood of using the iPod following the implementation of the device [26]. The existing drawbacks in mobile devices may inhibit their wide use and adoption in specific settings. It is clear that existing technical, contextual, and cost factors merit attention when implementing a mobile program to enhance e-learning and teaching and support clinical practice.

The review shows that there is scarce evidence demonstrating how the implementation or deployment of mobile devices impacted any knowledge gain, skill building, and attitude change pertaining to core competences in outcome-based curricula or education. Only one study reported promising results on the efficacy of mobile and digital support for a structured, competency-based curriculum for a residency program [17]. Future work should focus on developing, implementing, and evaluating a mobile program or intervention within the framework of competence requirements for undergraduate medical students, competence requirements for residents (the 
Accreditation Council for Graduate Medical Education or ACGME) [42], Entrustable

Professional Activities (EPA) for entering residents [43], or competence requirements for nursing and allied health education. Research efforts are needed to determine whether such a mobile program or intervention can improve competence-based outcomes and thus augment educational and clinical outcomes for students.

The review shows that there is a broad variation in how each study was conducted. The single group pretest-posttest design and single group posttest only design contributed to the majority of research designs in the selected studies with populations of varying sample sizes. Single-group pretest-posttest studies with participants acting as their control are susceptible to numerous validity threats such as history, maturation, testing, and instrumentation [13]. Moreover, there was over reliance on questionnaires as data collection measures of the efficacy of mobile devices in specific or local programs. The results in the qualitative synthesis based on self-reports and perceptions of using different types of mobile devices make it difficult to draw firm conclusions about the impact of mobile devices and also limit valid generalizability to different groups of health professions students across diverse educational programs in various settings. Further empirical research with large sample sizes and mixed research methods and triangulation techniques as demonstrated in reports $[18,22]$ is needed to build up a strong evidence base on the long-term efficacy of mobile technologies incorporated in educational curricula, student learning, patient care, and knowledge management.

The studies reviewed fell short of using standardized outcome measures to assess the impact of mobile device use. There was no evidence of reliability testing for the questionnaires used in 17 studies. Scant evidence of face and content validity was provided in three studies $[16,19,20]$. Future investigative work on psychometric properties of a subjective and objective mobile technology metrics or measurement instrument would contribute to the development of a reliable and valid measurement to assess outcomes of mobile technology integrated into curricula of health professions education beyond the internal, local, or institutional application. The line of 
research with rigorous methodology design would facilitate cross-institutional research and enhance generalizability of results to health professions students across different programs.

\section{Limitations}

While the authors made every effort to conduct comprehensive literature searches for all relevant articles published during the defined time period and to peer-review strategies or statements for all databases and resources searched, there is likelihood that pertinent articles might be missed. Research shows that more positive results than negative results are more likely to be published in an international, English-language journal [44] and that positives studies are 3 times more likely to be published than negative studies $[45,46]$. The magnitude and direction of a study's results may, to a greater extent, determine the summary effect of results in a quantitative review or metaanalysis. This is a qualitative systematic review; search results limited to published literature written in English could potentially introduce language and publication bias to the review.

\section{CONCLUSIONS}

Notwithstanding the drawbacks inherent in various types of mobile devices, the rapid development of mobile technologies will give rise to new and creative opportunities to design learning differently, extend learning spaces in real and virtual worlds, and foster a habit of lifelong learning. The findings of the systematic review suggest significant implications for health sciences libraries in allocating resources for acquiring mobile devices and apps and developing specific learning resources and mobile programs integrated into curricula and busy clinical workflow. The future of mobile devices will likely lead to health sciences librarians' expanded role in integrating mobile technology mediated information resources access in health professions education. 


\section{REFERENCES}

1. An interview with Tom Davenport and Larry Prusak, about their new book: working knowledge: how organizations manage what they know [Internet]; 2005 [cited 1 Jun 2015]. <http://www.brint.com/km/davenport/working.htm>.

2. Lucier RE. Building a digital library for the health sciences: information space complementing information place. Bull Med Libr Assoc. 1995 Jul;83(3):346-50.

3. Plutchak TS. Breaking the barriers of time and space: the dawning of the great age of librarians. J Med Libr Assoc. 2012 Jan;100(1):10-19. DOI: http://dx.doi.org/10.3163/15365050.100.1.004.

4. Gaglani SM, Topol EJ. iMedEd: the role of mobile health technologies in medical education. Acad Med. 2014 Sep;89(9):1207-1209. DOI:

http://dx.doi.org/10.1097/ACM.0000000000000361.

5. Su KW, Liu CL. A mobile Nursing Information System based on human-computer interaction design for improving quality of nursing. J Med Syst. 2012 Jun;36(3):1139-153. DOI: http://dx.doi.org/10.1007/s10916-010-9576-y.

6. Raman J. Mobile technology in nursing education: where do we go from here? A review of the literature. Nurse Educ Today. 2015 May;35(5):663-72. DOI: http://dx.doi.org/ 10.1016/j.nedt.2015.01.018.

7. Stokes A, Light J, Haines LL. Library support of mobile resources during clinical clerkships. Med Ref Serv Q. 2014;33(2):179-94. DOI: http://dx.doi.org/ 10.1080/02763869.2014.897519.

8. Klatt CA. Going mobile: free and easy. Med Ref Serv Q. 2011;30(1):56-73. DOI: http://dx.doi.org/10.1080/02763869.2011.540214.

9. Rosario JA, Ascher MT, Cunningham DJ. A study in usability: redesigning a health sciences library's mobile site. Med Ref Serv Q. 2012;31(1):1-13. DOI: http://dx.doi.org/ $10.1080 / 02763869.2012 .641481$. 
10. Boruff JT, Bilodeau E. Creating a mobile subject guide to improve access to point-ofcare resources for medical students: a case study. J Med Libr Assoc. 2012 Jan;100(1):55-60. DOI: http://dx.doi.org/10.3163/1536-5050.100.1.010.

11. Ludwig L, Starr S. Library as place: results of a delphi study. J Med Libr Assoc. 2005 Jul;93(3):315-26.

12. Gall MD, Gall JP, Borg WR. Educational research: an introduction. 8th ed. Boston, MA: Pearson Education; 2007.

13. Cook DA, Beckman TJ. Reflections on experimental research in medical education. Adv Health Sci Educ Theory Pract. 2010 Aug;15(3):455-64. DOI: http://dx.doi.org/ 10.1007/s10459008-9117-3.

14. Gruppen LD. Improving medical education research. Teach Learn Med. 2007 Fall;19(4):331-35.

15. Tashakkori A, Teddlie C. Mixed methodology : combining qualitative and quantitative approaches. Thousand Oaks, CA: Sage; 1998.

16. Bruce-Low SS, Burnet S, Arber K, Price D, Webster L, Stopforth M. Interactive mobile learning: a pilot study of a new approach for sport science and medical undergraduate students. Adv Physiol Educ. 2013;37(4):292-97. DOI: http://dx.doi.org/ 10.1152/advan.00004.2013.

17. Gonzalez NR, Dusick JR, Martin NA. Effects of mobile and digital support for a structured, competency-based curriculum in neurosurgery residency education. Neurosurgery. 2012 Jul;71(1):164-72. DOI: http://dx.doi.org/ 10.1227/NEU.0b013e318253571b.

18. Nuss MA, Hill JR, Cervero RM, Gaines JK, Middendorf BF. Real-time use of the iPad by third-year medical students for clinical decision support and learning: a mixed methods study. $\mathrm{J}$ Community Hosp Intern Med Perspect. 2014 Sept;4(4). DOI: http://dx.doi.org/ 10.3402/jchimp.v4.25184.

19. Mui K, Hun P, Sung T, Ling H, Suang C, Tina S. Evaluation of the use of iPod Touch drug guide by nursing students. Singapore Nurs J. 2014 Jan-Mar;41(1):10-14. 
20. Morris J, Maynard V. Pilot study to test the use of a mobile device in the clinical setting to access evidence-based practice resources. Worldviews Evid Based Nurs. 2010 Dec;7(4):205213. DOI: http://dx.doi.org/10.1111/j.1741-6787.2009.00171.x.

21. Berkowitz SJ, Kung JW, Eisenberg RL, Donohoe K, Tsai LL, Slanetz PJ. Resident iPad use: has it really changed the game? J Am Coll Radiol. 2014 Feb;11(2):180-184. DOI: http://dx.doi.org/10.1016/j.jacr.2013.04.017.

22. Davies BS, Rafique J, Vincent TR, et al. Mobile Medical Education (MoMEd) - how mobile information resources contribute to learning for undergraduate clinical students - a mixed methods study. BMC Med Educ. 2012;12:1. DOI: http://dx.doi.org/ 10.1186/1472-6920-12-1. 23. Hardyman W, Bullock A, Brown A, Carter-Ingram S, Stacey M. Mobile technology supporting trainee doctors' workplace learning and patient care: an evaluation. BMC Med Educ. 2013;13:6. DOI: http://dx.doi.org/10.1186/1472-6920-13-6.

24. Sharpe Iii EE, Kendrick M, Strickland C, Dodd Iii GD. The radiology resident iPad toolbox: An educational and clinical tool for radiology residents. J Am Coll Radiol. 2013;10(7):527-532. DOI: http://dx.doi.org/10.1016/j.jacr.2013.02.007.

25. Alegria DAH, Boscardin C, Poncelet A, Mayfield C, Wamsley M. Using tablets to support self-regulated learning in a longitudinal integrated clerkship. Med. Educ. Online. 2014;19:23638. DOI: http://dx.doi.org/10.3402/meo.v19.23638.

26. Mann EG, Medves J, Vandenkerkhof EG. Accessing best practice resources using mobile technology in an undergraduate nursing program: a feasibility study. 2015 Mar;33(3):122-28. DOI: http://dx.doi.org/ 10.1097/CIN.0000000000000135.

27. Johansson PE, Petersson GI, Nilsson GC. Nursing students' experience of using a personal digital assistant (PDA) in clinical practice - an intervention study. Nurs Educ Today. 2013 Oct;33(10):1246-251. DOI: http://dx.doi.org/10.1016/j.nedt.2012.08.019. 
28. Brown J, Mc CP. The iPad: tablet technology to support nursing and midwifery student learning: an evaluation in practice. Comput Inform Nurs. 2015 Mar;33(3):93-8. DOI: http://dx.doi.org/10.1097/CIN.0000000000000131.

29. George P, Newey CR, Bhimraj A. The tablet device in hospital neurology and in neurology graduate medical education: a preliminary study. The Neurohospitalist. 2015 Jan;5(1):15-21. DOI: http://dx.doi.org/10.1177/1941874414548802.

30. Shurtz S, von Isenburg M. Exploring e-readers to support clinical medical education: two case studies. J Med Libr Assoc. 2011Apr;99(2):110-17. DOI: http://dx.doi.org/ 10.3163/15365050.99.2.002.

31. Tanaka PP, Hawrylyshyn KA, Macario A. Use of tablet (iPad®) as a tool for teaching anesthesiology in an orthopedic rotation. Rev Bras Anestesiol. 2012 Mar-Apr;62(2):214-22. DOI: http://dx.doi.org/10.1016/S0034-7094(12)70119-8.

32. Byrne-Davis L, Dexter H, Hart J, et al. Just-in-time research: a call to arms for research into mobile technologies in higher education. Res Learn Techno. 2015;23: 25653. http://dx.doi.org/10.3402/rlt.v23.25653.

33. Goldbach H, Chang AY, Kyer A, et al. Evaluation of generic medical information accessed via mobile phones at the point of care in resource-limited settings. J Am Med Inform Assoc. 2014 Jan-Feb;21(1):37-42. DOI: http://dx.doi.org/10.1136/amiajnl-2012-001276.

34. Friederichs H, Marschall B, Weissenstein A. Practicing evidence based medicine at the bedside: a randomized controlled pilot study in undergraduate medical students assessing the practicality of tablets, smartphones, and computers in clinical life. BMC Med Inform Decis Mak. 2014 Dec;14(1):113. DOI: http://dx.doi.org/10.1186/s12911-014-0113-7.

35. Wittmann-Price RA, Kennedy LD, Godwin C. Use of personal phones by senior nursing students to access health care information during clinical education: staff nurses' and students' perceptions. J Nurs Educ. 2012 Nov;51(11):642-46. DOI: http://dx.doi.org/10.3928/0148483420120914-04. 
36. Hudson K, Buell V. Empowering a safer practice: PDAs are integral tools for nursing and health care. J Nurs Manag. 2011Apr;19(3):400-06. DOI: http://dx.doi.org/10.1111/j.13652834.2011.01251.x.

37. Berkowitz SJ, Kung JW, Eisenberg RL, Donohoe K, Tsai LL, Slanetz PJ. Resident iPad use: has it really changed the game? J Am Coll Radiol. 2013 Feb;11:180-184. DOI: http://dx.doi.org/10.1016/j.jacr.2013.04.017.

38. Johansson PE, Petersson GI, Nilsson GC. Nursing students' experience of using a personal digital assistant (PDA) in clinical practice - an intervention study. Nurs Educ Today. 2013 Oct;33(10):1246-251. DOI: http://dx.doi.org/10.1016/j.nedt.2012.08.019.

39. Morris J, Maynard V. Pilot study to test the use of a mobile device in the clinical setting to access evidence-based practice resources. Worldviews Evid Based Nurs. 2010 Dec;7(4):20513. DOI: http://dx.doi.org/10.1111/j.1741-6787.2009.00171.x.

40. Goldbach H, Chang AY, Kyer A, et al. Evaluation of generic medical information accessed via mobile phones at the point of care in resource-limited settings. J Am Med Inform Assoc. 2014 Jan-Feb;21(1):37-42. DOI: http://dx.doi.org/10.1136/amiajnl-2012-001276.

41. CASP checklist. [Internet]. Critical Appraisal Skills Programme; 2013 [cited 22 Mar 2015]. <http://www.casp-uk.net/\#!checklists/cb36>.

42. Ling L, Derstine P, Cohen N. Implementing milestones and clinical competency committees. [Internet]. The Accreditation Council for Graduate Medical Education; 2013 [cited 30 May 2015]. <https://www.acgme.org/acgmeweb/Portals/0/PDFs/ACGMEMilestones-CCCAssesmentWebinar.pdf $>$.

43. Core entrustable professional activities for entering residency [Internet]. Association of American Medical College; 2014 [cited 28 May 2015]. 〈http://www.aamc.org/cepaer>.

44. Egger M, Dickersin K, Smith GD, editors. Systematic reviews in health care : metaanalysis in context. 2nd ed. London: BMJ Publishing Group; c2001. Chapter 3, Problems and limitations in conducting systematic reviews; p. 43-68. 
45. Stern JM, Simes RJ. Publication bias: evidence of delayed publication in a cohort study of clinical research projects. BMJ. 1997 Sep;315(7109):640-45.

46. Egger M, Smith GD. Bias in location and selection of studies. BMJ. 1998 Jan;316 (7124):61-66. 
Table 1

Characteristics of 20 Studies

\begin{tabular}{|c|c|c|c|c|c|}
\hline Source & $\begin{array}{l}\text { Population, sample } \\
\text { size, setting }\end{array}$ & $\begin{array}{l}\text { Mobile device, } \\
\text { duration of } \\
\text { intervention }\end{array}$ & Study design & $\begin{array}{l}\text { Data collection } \\
\text { method }\end{array}$ & Resources accessed/used \\
\hline $\begin{array}{l}\text { Alegria et } \\
\text { al. }[25]\end{array}$ & $\begin{array}{l}15 \text { third year medical } \\
\text { students; clinical setting, } \\
\text { USA }\end{array}$ & $\begin{array}{l}\text { Tablet } \\
\text { computers; } 1 \\
\text { year }\end{array}$ & Qualitative research & $\begin{array}{l}2 \text { one-hour focus } \\
\text { groups }\end{array}$ & $\begin{array}{l}\text { Banks of practice questions for national texts; } \\
\text { collected learning resources }\end{array}$ \\
\hline $\begin{array}{l}\text { Berkowitz } \\
\text { et al. [21] }\end{array}$ & $\begin{array}{l}38 \text { radiology residents; } \\
\text { clinical setting, USA }\end{array}$ & iPad; 6 months & $\begin{array}{l}\text { Quantitative research } \\
\text { (single group posttest } \\
\text { only design) }\end{array}$ & $\begin{array}{l}\text { Online } \\
\text { questionnaire }\end{array}$ & $\begin{array}{l}\text { Radiology specific applications: e-Anatomy, } \\
\text { Radiology and RadioGraphics; Web browsers, } \\
\text { e-mail client, PDF file reader; journals articles }\end{array}$ \\
\hline $\begin{array}{l}\text { Brown and } \\
\text { McCrorie } \\
{[28]}\end{array}$ & $\begin{array}{l}30 \text { first-year BSN } \\
\text { students, } 88 \text { final } \\
\text { semester BSN students, } \\
\text { \& } 25 \text { BS midwifery } \\
\text { students; clinical } \\
\text { laboratory, academic } \\
\text { setting, } \\
\text { Australia }\end{array}$ & $\begin{array}{l}\text { iPads; } \\
1 \text { semester }\end{array}$ & $\begin{array}{l}\text { Quantitative research } \\
\text { (single group posttest } \\
\text { only design) }\end{array}$ & $\begin{array}{l}\text { Online } \\
\text { questionnaire }\end{array}$ & $\begin{array}{l}\text { Clinical guidelines; readily available references } \\
\text { when needed }\end{array}$ \\
\hline $\begin{array}{l}\text { Bruce-Low } \\
\text { et al. [16] }\end{array}$ & $\begin{array}{l}28 \text { first year sports } \\
\text { medicine undergraduate } \\
\text { students, } 27 \text { first year } \\
\text { medical students; } \\
\text { academic setting, UK }\end{array}$ & $\begin{array}{l}\text { Samsung NC10 } \\
\text { Netbook/3 } \\
\text { weeks }\end{array}$ & $\begin{array}{l}\text { Mixed methods } \\
\text { research: quantitative } \\
\text { (pretest-posttest } \\
\text { control-group design } \\
\text { with random) } \\
\text { assignment) and } \\
\text { qualitative research }\end{array}$ & $\begin{array}{l}\text { Pretest and } \\
\text { posttest tests; } \\
\text { focus group }\end{array}$ & $\begin{array}{l}\text { Netbooks loaded with a video on the ECG } \\
\text { technique, multiple choice questions and } \\
\text { interactive exercise }\end{array}$ \\
\hline
\end{tabular}




\begin{tabular}{|c|c|c|c|c|c|}
\hline $\begin{array}{l}\text { Davies et al. } \\
\text { [22] }\end{array}$ & $\begin{array}{l}387 \text { year three-five year } \\
\text { medical students; } \\
\text { clinical setting, UK }\end{array}$ & $\begin{array}{l}\text { Hewlett Packard } \\
\text { iPAQ } 114 \text { PDA; } \\
3 \text { years }\end{array}$ & $\begin{array}{l}\text { Mixed methods } \\
\text { research: qualitative } \\
\text { research (focus group, } \\
\text { usage data) and } \\
\text { quantitative research } \\
\text { (one-group pretest- } \\
\text { posttest design) }\end{array}$ & $\begin{array}{l}4 \text { focus groups; } \\
\text { questionnaire; } \\
\text { usage } \\
\text { monitoring data }\end{array}$ & $\begin{array}{l}\text { British National Formulary and Oxford } \\
\text { Handbook of Clinical medicine as the most } \\
\text { popular onces; other resources including } \\
\text { medical dictionary, Netter's anatomy, and quick } \\
\text { references }\end{array}$ \\
\hline $\begin{array}{l}\text { Friederich et } \\
\text { al. [34] }\end{array}$ & $\begin{array}{l}120 \text { third-year medical } \\
\text { students; clinical setting, } \\
\text { Germany }\end{array}$ & $\begin{array}{l}\text { PC, iPads, iPods, } \\
\text { Smartphones; } \\
\text { duration not } \\
\text { reported }\end{array}$ & $\begin{array}{l}\text { Quantitative research } \\
\text { (pretest-posttest } \\
\text { control-group design } \\
\text { with randomized } \\
\text { assignment) }\end{array}$ & Questionnaire & $\begin{array}{l}\text { Searched Unbound Medline (app), a search } \\
\text { platform }\end{array}$ \\
\hline $\begin{array}{l}\text { George et } \\
\text { al. [29] }\end{array}$ & $\begin{array}{l}27 \text { year 2, 3, } 4 \text { level } \\
\text { neurology residents, } \\
\text { clinical setting, USA }\end{array}$ & iPad; 1 year & $\begin{array}{l}\text { Quantitative research } \\
\text { (one-shot case study) }\end{array}$ & $\begin{array}{l}\text { Online } \\
\text { Questionnaire }\end{array}$ & $\begin{array}{l}\text { Preloaded neurological applications and journal } \\
\text { articles selected by attending staff and chief } \\
\text { residents pertaining to the American Board of } \\
\text { Psychiatry and Neurology syllabus, and the } \\
\text { EMR; AAN Neurology app; Journal articles via } \\
\text { the integrated web browser and secured } \\
\text { Intranet; DropBox to access preloaded } \\
\text { neurologic journal articles }\end{array}$ \\
\hline $\begin{array}{l}\text { Goldbach et } \\
\text { al. [40] }\end{array}$ & $\begin{array}{l}18 \text { first year residents in } \\
\text { internal medicine, } \\
\text { pediatrics, emergency } \\
\text { medicine, and family } \\
\text { medicine programs/ } \\
\text { Clinical setting/ } \\
\text { Botswana }\end{array}$ & $\begin{array}{l}\text { Smart phones } \\
\text { (myTouch } 3 \mathrm{G} \\
\text { Slide HTC } \\
\text { Android)/3 } \\
\text { months }\end{array}$ & $\begin{array}{l}\text { Quantitative research } \\
\text { (crossover design) }\end{array}$ & $\begin{array}{l}\text { Questions based } \\
\text { on clinical } \\
\text { scenarios }\end{array}$ & $\begin{array}{l}\text { PubMed abstracts via the PubMed for } \\
\text { Handhelds (PubMed4Hd) website; } \\
\text { medical/drug reference applications (Medical } \\
\text { Apps) accessed via locally loaded software on } \\
\text { the mobile phone; medical apps as follows: } \\
\text { Medscape, Unbound Medicine, Skyscape } \\
\text { (including MedAlert, Archimedes, Dynamed, }\end{array}$ \\
\hline
\end{tabular}




\begin{tabular}{|c|c|c|c|c|c|}
\hline & & & & & $\begin{array}{l}\text { Outlines in Clinical Medicine, RxDrugs), and } \\
\text { ePocrates Rx }\end{array}$ \\
\hline $\begin{array}{l}\text { Gonzalez et } \\
\text { al. [17] }\end{array}$ & $\begin{array}{l}12 \text { neurosurgery } \\
\text { residents; clinical } \\
\text { setting, USA }\end{array}$ & Tablets; 1 year & $\begin{array}{l}\text { Quantitative research } \\
\text { (one-group pretest- } \\
\text { posttest design) }\end{array}$ & $\begin{array}{l}\text { Survey; pretest- } \\
\text { posttest self- } \\
\text { assessment in } \\
\text { Neurological } \\
\text { Surgery (SANS) } \\
\text { examination }\end{array}$ & $\begin{array}{l}\text { Videos of presentations stored and broadcasted } \\
\text { on a digital library on a website and iTunes U; } \\
\text { the digital library including neurosurgery } \\
\text { textbooks, relevant articles, and collections of } \\
\text { operative pictures and videos; tablet devices } \\
\text { installed with free and paid applications for } \\
\text { management of documents, video, and } \\
\text { interactive teaching tools (e.g. 3D Brain, } \\
\text { AllOfwWiki Online, Brain Tutor, Epocrates, } \\
\text { Eye Test Chart Pro, Pocket First Aid \& CPR, } \\
\text { GoodReader, KeyNote, Kindle Reader, etc.), } \\
\text { and some commercially available } \\
\text { neuroanatomy and neuroradiology tools }\end{array}$ \\
\hline $\begin{array}{l}\text { Hardyman } \\
\text { et al. [23] }\end{array}$ & $\begin{array}{l}260 \text { participants } \\
\text { including F1 and F2 } \\
\text { trainees, fourth and fifth } \\
\text { medical students, } \\
\text { clinical fellows, and } \\
\text { other type of trainees; } \\
\text { clinical setting, UK }\end{array}$ & $\begin{array}{l}\text { Smartphone/ } \\
\text { pilot phase; } 6 \\
\text { months; main } \\
\text { phase; } 5 \text { months } \\
\text { (the paper only } \\
\text { reports the } \\
\text { evaluation of the } \\
\text { main phase) }\end{array}$ & $\begin{array}{l}\text { Mixed methods } \\
\text { research: quantitative } \\
\text { research (one-group } \\
\text { pretest-posttest study) } \\
\text { and qualitative research } \\
\text { (written case reports of } \\
\text { usage) }\end{array}$ & $\begin{array}{l}\text { Questionnaires; } \\
\text { survey; case } \\
\text { reports }\end{array}$ & $\begin{array}{l}\text { A Library of } 17 \text { textbooks on a micro secure } \\
\text { digital (SD) card pre-loaded with a software } \\
\text { application including: British National } \\
\text { Formulary (BNF), the Oxford Handbook of } \\
\text { Clinical Medicine, the Oxford Handbook of the } \\
\text { Foundation Programme and Netter's Atlas of } \\
\text { Human Anatomy-all included in Medhand's } \\
\text { Universal Mobile Library and searchable with } \\
\text { an electronic application DocTool Cross } \\
\text { Library Search Tool }\end{array}$ \\
\hline $\begin{array}{l}\text { Hudson and } \\
\text { Buell [36] }\end{array}$ & $\begin{array}{l}105 \text { undergraduate } \\
\text { nursing students; both }\end{array}$ & PDAs; 2 year & $\begin{array}{l}\text { Quantitative research } \\
\text { (one-group pretest- } \\
\text { posttest study) }\end{array}$ & Questionnaires & $\begin{array}{l}\text { Drug references; the top } 5 \text { frequently used PDA } \\
\text { resources are (from most to least): drug }\end{array}$ \\
\hline
\end{tabular}




\begin{tabular}{|c|c|c|c|c|c|}
\hline & $\begin{array}{l}\text { classroom and clinical } \\
\text { settings, USA }\end{array}$ & & & & $\begin{array}{l}\text { references, patient teaching, laboratory guide, } \\
\text { pathophysiology, nursing procedures. }\end{array}$ \\
\hline $\begin{array}{l}\text { Johansson et } \\
\text { al. [27] }\end{array}$ & $\begin{array}{l}67 \text { nursing students; } \\
\text { clinical practice (rural } \\
\text { district health services in } \\
\text { sheltered } \\
\text { accommodations, } \\
\text { patients home, } \\
\text { university healthcare } \\
\text { center), Sweden }\end{array}$ & $\begin{array}{l}\text { PDAs(Palm } \\
\text { TX); } 15 \text { weeks }\end{array}$ & $\begin{array}{l}\text { Mixed methods } \\
\text { research: quantitative } \\
\text { research (one group } \\
\text { protest and posttest } \\
\text { study) and qualitative } \\
\text { research }\end{array}$ & $\begin{array}{l}\text { Questionnaire; } 7 \\
\text { focus groups }\end{array}$ & $\begin{array}{l}\text { Pharmaceutical and medical resources freely } \\
\text { downloaded from the Internet: FASS (an } \\
\text { encyclopedia with information about the } \\
\text { medicines that have marketing authorization in } \\
\text { Sweden), Med Calc, guidelines/techniques for } \\
\text { treatment, and acts and regulations for nursing; } \\
\text { word processing program, calculator and } \\
\text { calendar; other medical information and } \\
\text { calculation }\end{array}$ \\
\hline $\begin{array}{l}\text { Mann et al. } \\
{[26]}\end{array}$ & $\begin{array}{l}33 \text { nursing students; } \\
\text { clinical setting, Canada }\end{array}$ & $\begin{array}{l}\text { iPod Touch; } 2 \\
\text { years }\end{array}$ & $\begin{array}{l}\text { Quantitative research } \\
\text { (one group pretest- } \\
\text { posttest study) }\end{array}$ & $\begin{array}{l}\text { Questionnaires; } \\
\text { group meetings } \\
\text { (month } 7 \text { and } \\
\text { 11); online } \\
\text { feedback }\end{array}$ & $\begin{array}{l}\text { Applications including medical calculator, } \\
\text { RNAO BPGs, Normal Lab Values, and Drug \& } \\
\text { Drug Interaction- Medscape; additional } \\
\text { applications, e.g., Lippincott's Nursing Drug } \\
\text { Guide and an application to check normal } \\
\text { laboratory values }\end{array}$ \\
\hline $\begin{array}{l}\text { Morris } \\
\text { and } \\
\text { Maynard } \\
\text { [39] }\end{array}$ & $\begin{array}{l}9 \text { physiotherapy students } \\
\text { and } 10 \text { nursing students; } \\
\text { clinical care setting, UK }\end{array}$ & $\begin{array}{l}\text { HP iPAQ; } 4-5 \\
\text { week }\end{array}$ & $\begin{array}{l}\text { Quantitative research } \\
\text { (one group pretest- } \\
\text { posttest study) }\end{array}$ & Questionnaires & Clinical guidelines; EBP resources \\
\hline $\begin{array}{l}\text { Mui } \\
\text { et al. [19] }\end{array}$ & $\begin{array}{l}578 \text { nursing students; } \\
\text { academic setting, } \\
\text { Singapore }\end{array}$ & $\begin{array}{l}\text { iPod Touch; } 1 \\
\text { year }\end{array}$ & $\begin{array}{l}\text { Quantitative research } \\
\text { (one-shot case study) }\end{array}$ & Questionnaire & $\begin{array}{l}\text { Apps for iPod touch including the NPALM } \\
\text { nursing assessment (an e-logbook) and the } \\
\text { NPALM drug guide }\end{array}$ \\
\hline
\end{tabular}




\begin{tabular}{|c|c|c|c|c|c|}
\hline $\begin{array}{l}\text { Nuss } \\
\text { et al. [18] }\end{array}$ & $\begin{array}{l}37 \text { third year medical } \\
\text { students; clinical setting, } \\
\text { USA }\end{array}$ & iPads; 1 year & $\begin{array}{l}\text { Mixed methods } \\
\text { research: quantitative } \\
\text { (one group pretest- } \\
\text { posttest study) } \\
\text { and qualitative design }\end{array}$ & $\begin{array}{l}\text { Pre- and post- } \\
\text { questionnaire; } \\
\text { weekly } \\
\text { observations; } \\
\text { semi-structured } \\
\text { one-on-one } \\
\text { interviews; } \\
\text { weekly usage } \\
\text { logs }\end{array}$ & $\begin{array}{l}\text { Top apps recorded in the iPad usage logs } \\
\text { included Micromedex, DynaMed, and } \\
\text { Epocrates; other widely used apps including } \\
\text { First Consult†, DrawMD, USMLE World Q } \\
\text { Bank, Medical School Library, PDFExpert, } \\
\text { Pocket Lab Values, VisualDx }\end{array}$ \\
\hline $\begin{array}{l}\text { Sharpe } \\
\text { et al. [24] }\end{array}$ & $\begin{array}{l}34 \text { radiology residents; } \\
\text { clinical setting, USA }\end{array}$ & iPads; 3 months & $\begin{array}{l}\text { Quantitative research } \\
\text { (one short case study) }\end{array}$ & Online survey & $\begin{array}{l}\text { Electronic textbooks; anatomy atlases; online } \\
\text { resources such as StatDx; journal articles and } \\
\text { professional society guidelines }\end{array}$ \\
\hline $\begin{array}{l}\text { Shurtz } \\
\text { and } \\
\text { Isenburg } \\
{[30]}\end{array}$ & $\begin{array}{l}15 \text { second year medical } \\
\text { students, } 9 \text { fourth year } \\
\text { medical students, } 7 \\
\text { clerkship preceptors, } \\
6 \text { residents; primary care } \\
\text { setting, } \\
\text { USA }\end{array}$ & $\begin{array}{l}\text { Kindle e-reader/ } \\
4 \text { weeks for one } \\
\text { case study; } 3 \\
\text { months for med } \\
\text { student and } 3 \\
\text { weeks for } \\
\text { residents in } \\
\text { another case } \\
\text { study }\end{array}$ & Quantitative research & $\begin{array}{l}\text { Online survey; } \\
\text { self-guided e- } \\
\text { reader exercises }\end{array}$ & Ebooks; PubMed \\
\hline $\begin{array}{l}\text { Tanaka et } \\
\text { al. [31] }\end{array}$ & $\begin{array}{l}9 \text { orthopedics residents; } \\
\text { clinical setting, USA }\end{array}$ & iPad; 2 weeks & $\begin{array}{l}\text { Quantitative research } \\
\text { (one-group pretest- } \\
\text { posttest design) }\end{array}$ & Online survey & $\begin{array}{l}\text { Core articles; daily schedule of reading } \\
\text { assignments, pre-selected peer reviewed internet } \\
\text { sites; online textbooks }\end{array}$ \\
\hline
\end{tabular}




\begin{tabular}{|l|l|l|l|l|l|}
\hline $\begin{array}{l}\text { Wittmann- } \\
\text { Price et al. } \\
{[35]}\end{array}$ & $\begin{array}{l}\text { 6 nursing students, 5 } \\
\text { nursing staff; clinical } \\
\text { setting, USA }\end{array}$ & $\begin{array}{l}\text { Smartphone; 10 } \\
\text { weeks }\end{array}$ & $\begin{array}{l}\text { Qualitative research } \\
\text { (focus group and usage } \\
\text { log) }\end{array}$ & $\begin{array}{l}\text { Focus group; } \\
\text { usage log for } \\
\text { nursing students; } \\
\text { written survey } \\
\text { for nursing staff } \\
\text { members }\end{array}$ & $\begin{array}{l}\text { Electronic reference package purchased and } \\
\text { placed on all participants' smartphones (MEDs); } \\
\text { medication administration }\end{array}$ \\
\hline
\end{tabular}

